\title{
INTEGRATION OF UKRAINIAN INDUSTRY INTO THE GLOBAL VALUE CHAINS*
}

\author{
Kristina Stelmakh \\ $\mathrm{PhD}$ in economics, scientific researcher \\ SI "The Institute of Regional Research \\ Named after M. I. Dolishniy of the NAS of Ukraine" \\ Kozelnytska Str. 4, Lviv, 79026 \\ e-mail: stelmakhkristina@gmail.com \\ ORCID: https:/ / orcid.org/0000-0001-6094-8790
}

\begin{abstract}
The paper examines the forming of global chains and defines the features of their forming on the example of machine-building enterprises. Outlining the integration of the Ukrainian industry into the global value chains is the subject of the research. The paper aims to develop the provisions regarding the establishment of global value chains in modern economic conditions. Many researchers argue that globalization has contributed to a kind of global economic optimization. The outbreak of COVID-19 causes the current economic recession and a simultaneous complete reorientation of global trade logistics. The analysis of the features of offshoring on the example of the functioning of industrial enterprises in the country is the task of the research. The forming of a reliable system of suppliers monitoring that also represents the importance of selecting supply specialists is a decisive factor. Based on the system analysis the paper determines that despite the availability of obstacles to the location of foreign capital in Ukraine, there are certain perspectives for the integration of industrial enterprises into the global value chains. The results of the research show that despite the current socio-economic condition, Ukraine is attractive for foreign investment due to significant return on capital investment compared to the respective economic activity types of European countries, favorable geographic position, and availability of cheap but skilled workforce. An efficient socio-economic development is impossible without the high technology and innovative activity of the country. Yet, political instability and a set of barriers to foreign investment attraction remain to be the key problem for socio-economic development.

Key words: global value chains, foreign investment, regions, offshoring, outsourcing, industry, machine building, automotive industry.
\end{abstract}

\begin{abstract}
General problem statement and its connection with important scientific and practical tasks. Cross-border flows from investment in material production funds ceased growing in the second decade of the $21^{\text {st }}$ century, and the trade dynamics weakened. Therefore, the study of the problems of the Ukrainian industry's integration into the global value chains requires more attention.
\end{abstract}

In this regard, the studies of Kaplinsky R., Morris M., Neurov I., Karpova T., Filipenko A., Filipenko V., Shih S., Moravcsik A., Volkova Y., Shambost E., Sheremetynska O., and Kulytskyi S. should be noted.

The paper aims to develop the provisions regarding the establishment of global value chains in modern economic conditions.

Presentation of main research findings with complete substantiation of received scientific results. A global value chain is the full range of activities which are required to bring a product or service from conception, through the different phases of production (involving a combination of physical transformation and the input of various producer services), delivery to final consumers, and final disposal after use set of activities to develop products or services [1, p.4].

The term outsourcing means the use of external means [2, p. 156]. The ISO 9001:2000 standard provides that outsourcing is the process of transferring the non-core functions to be carried out by an external company. The long-term business links based on contract agreements between a company and an outsourcer are the main feature of outsourcing because the transferred function is the main type of activity for the outsourcer [3, 4].

Offshore outsourcing is the outsourcing with the participation of the outsourcing companies outside the customer country [3, p. 241].

The difference between outsourcing and offshoring is that offshoring is related to foreign economic activity. Outstaffing is attracting specialists from an agency " $B$ " not including them in the staff of a service customer. In other words, company "A" does not hire employees but rather

\footnotetext{
* Cite as: Stelmakh, K. (2021). Integration of Ukrainian Industry Into the Global Value Chains, The Journal of V. N. Karazin Kharkiv National University. Series: International Relations. Economics. Country Studies. Tourism. 13, 115-123.
} https://doi.org/10.26565/2310-9513-2021-13-12 
works with a legal entity "B", which has the necessary specialists for the business in its staff. Fig. 1 provides the main principle of the functioning of global value chains in the production of machine-building equipment. It should be mentioned, that in early 2018 the company Beijing Electric Power Automatic became interested in opportunities to produce busses on the basis of Stryi Bus Factory.
According to the Association of Automotive Companies of Ukraine, the companies plan to ground the production on cooperation between the Chinese company and Ukrainian TOV "BEEM - Metalavtoprom".

Table 1 provides the list of partners of TDV "Stryi-Avto" that are included in global value chains.

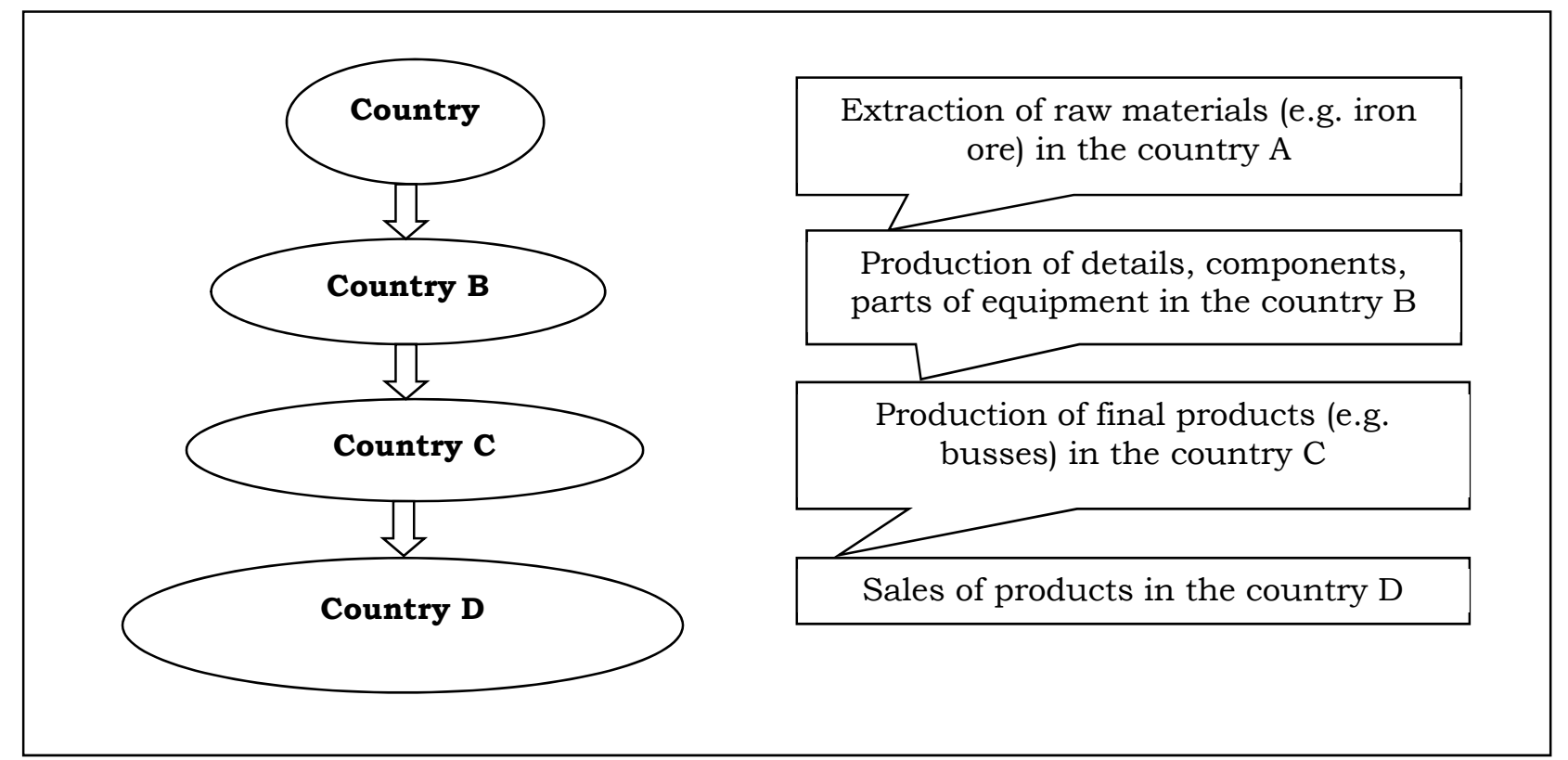

*Developed by the author

Fig. 1 Functioning of global value chains on the example of Stryi Bus Factory (TDV "Stryi-Avto")

Table 1

TDV "Stryi-Avto" and partner countries included in global value chains

\begin{tabular}{|c|c|c|c|}
\hline Country A & Country B & Country C & Country D \\
\hline Ukraine & $\begin{array}{c}\text { Turkey, } \\
\text { Poland }\end{array}$ & Poland & Poland, Germany \\
\hline
\end{tabular}

* Developed by the author

Meanwhile, the development of global value chains is often described as a non-linear process that represents a kind of arc that is called the smiling curve. The first to describe the smiling curve was CEO of ACER Computer's Stan Shih in 1992. According to Shih, the main idea of the curve is that less value is created in production or assembling than in previous (research, innovative activity, design) and following stages (logistics, marketing, after-sale service). S. Shih argues that in the course of production (assembling), a company gains profit only due to manual labor, while the higher value is created by intellectual labor [5, p. 174].

Such integrating economic methods require systematization, harmonization, coordination, and unification of economic and social policies. Harmonization, on the one hand, stipulates that a state keeps its control over economic processes, while on the other hand - it requires adaptation 116 of national legislation to jointly developed legal and regulating principles. Harmonization and decentralization are justified until they balance the distribution and consumption of social benefits within the integration entity. Moreover, the processes are sensitive to competitive policy, which aims to strengthen the market environment in the integration space. Coordination means voluntary harmonization of certain areas of economic policy. Unification occurs at higher levels of economic integration. For example, in the European Union, it covers the monetary policy. The methods and tools of international economic integration do not remain unchanged. They transform in the process of deepening and diversification of integration entities. In particular, modern scientific literature addresses such issues as neo-functionalism that stipulates the growing role of national governments in the process of integration and 
neo-institutionalism, when integration problems are solved at the supranational level by harmonization and development of joint economic policy [6, p. 9-11].

It is worth mentioning the theoretical generalizations of neo-functionalism representatives, primarily $E$. Haas. In addition to emphasizing the decisive role of political factor in the process of integration, namely as a factor of creating political communities [7], he also defines European integration as a quality process that cannot be equaled to international or intergovernmental cooperation.

Therefore, the UNCTAD Report (World Investment Report, WIR20) not only summarizes the COVID-19 impact on foreign direct investment but also outlines the future regarding the perspective development of the international production system in 2021-2030. The authors of the report try to suggest a comprehensive analytical basis to outline possible development ways and solutions in economic policy. 2030 is also a date of implementation of UN sustainable development goals. WIR20 emerges in a critical moment, making the evaluation of the impact of expected changes on foreign direct investment in the nearest future even more important. UNCTAD analyzes foreign direct investment and activity of transnational corporations in the last 30 years. In this period, international cooperation has gone through twenty years of dynamic growth and then ten years of stagnation, which was bound to impact the forming of respective business models of enterprises. Each of the formed business models has its attributes. Generalizing the modern interpretations of business models, one can assume that they include the description of the value suggested by an enterprise to a group or groups of consumers in addition to determining main resources, processes, and external relations of the enterprise that serve the objective of value creation and securing the competitiveness of the enterprise in a certain sector and contribute to increasing its value. The most often mentioned attributes of a business model are the following:

- a company's position in the value chain;

- resources;

- relations with partners;

- offered goods;

- consumer value;

- sources of income;

- competitiveness strategy;

- clients (market position).

Fig. 2 presents the developed provisions regarding the arrangement of forming of global value chains in modern economic conditions.

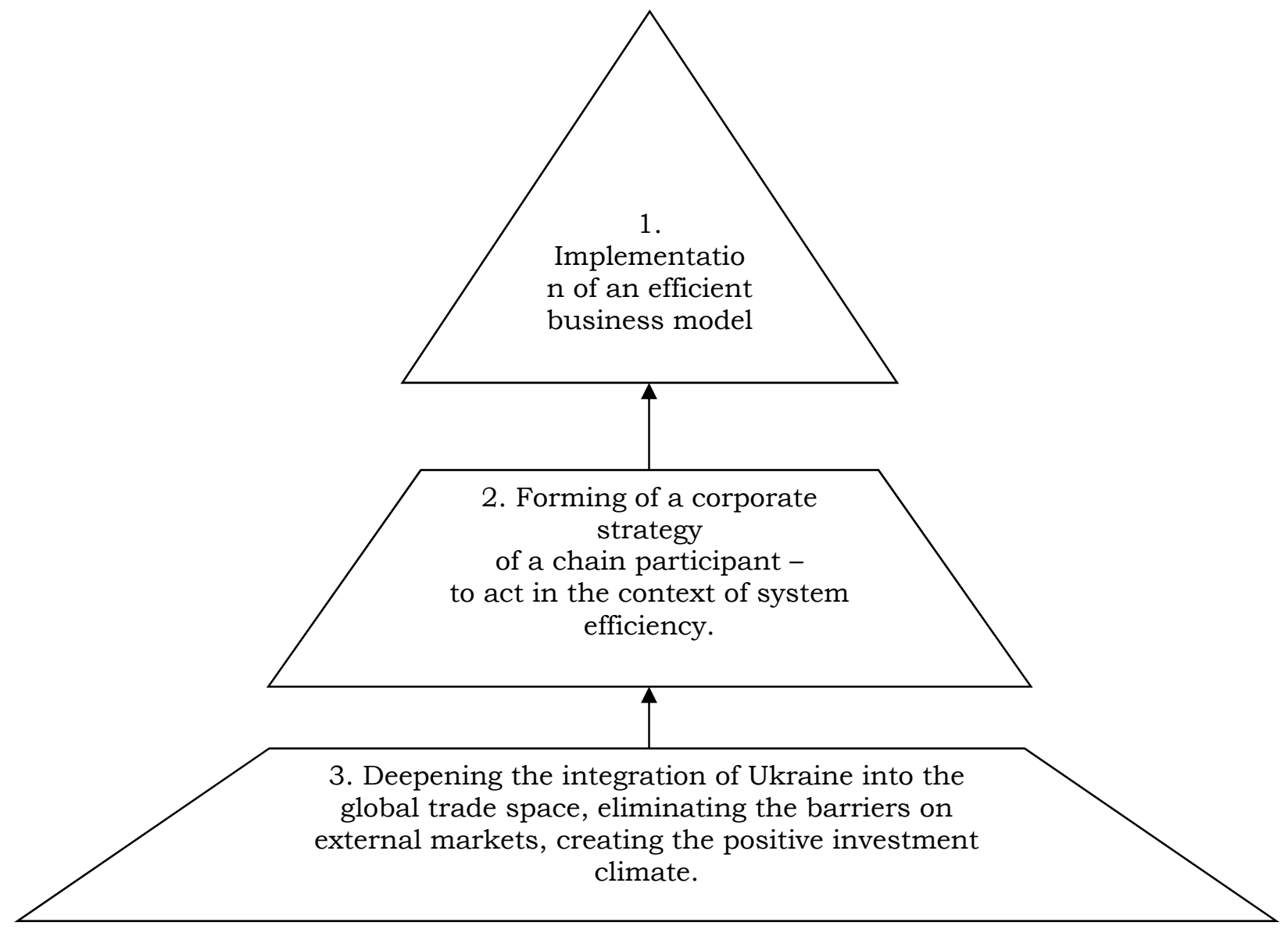

Fig. 2. Provisions regarding the arrangement of forming of global value chains in modern economic conditions *Developed by the author based on: [1-15] 
To efficiently implement the business model, the managers of a company, marketing, management, and finance departments should develop a single approach to the perspectives of conducting its production activity and forming of leading positions. At this stage, it is a question of producing competitive products because only the technology-intensive products can bring significant results in production. The respective human resources available at the enterprise are necessary to implement this business model.

In particular, the 2025 Technology-Intensive Sectors Development Strategy provides that international markets become increasingly accessible with the implementation of the EUUkraine Association Agreement and other trade agreements ratified by Ukraine. Yet, entrance to a foreign market is often a complicated task for business, so innovative enterprises require assistance, support, and qualified staff.

The second stage of forming the corporate strategy outlines the aspects of the enterprise's functioning considering globalization and its consequences, both positive and negative. The feature of this stage is the improvement of the existing business model, forming the global strategy for larger production volumes and increasing the production forces. It is peculiar to diversified companies, where top managers create a highly productive portfolio of economic departments and manage them; achieve a synergy of adjoining economic departments and turn it into a competitive advantage; define investment priorities and direct corporate resources to the most attractive business sectors.

An example is the strategy of General Motors. According to Strategies Journal, in 1932, its production had reduced by $72 \%$ compared to 1929, but the company did not go bankrupt. Moreover, it remained profit-making, although the profit had fallen from $\$ 248$ million in 1929 down to $\$ 165$ million in 1932 . General Motors headed by Alfred Sloan turned out to be ready to face a crisis. And it's not that Sloan predicted the course of events in a pessimistic scenario although there were many negative prognoses in the mid-1920s, same as in the mid-2000s. The nature of the selected business model and corporate strategy was in the coordination of internal policy, organizational structure, and administering decentralization.

The political instability of Ukraine is a negative factor on the way to forming and functioning of not only global value chains but also forming of international economic image of the country. The failures of socio-economic transitions that have caused, among other problems, the growing socioeconomic differentiation of regions brought the task of searching for new tools of efficient reforming from the background.

Therefore, deeper integration of Ukraine into the global trade space, elimination of barriers at external markets, and creation of positive investment climate open the opportunities, which the developed and developing countries should use to their advantage because there is a dependence between the growing participation of countries in global value chains and growing GDP. There are two new types of chains: value chains driven by consumers and chains driven by producers. The difference is important because the dynamics of relations and connections they generate differ.

Global value chains faced serious blows of the COVID-19 crisis. Meanwhile, the virus is not the only factor of these radical changes. The crisis caused by pandemics has contributed to previous powerful challenges faced by the transnational production system due to the new industrial revolution, existing economic nationalism, and the need to secure sustainable development.

IMF Managing Director Kristalina Georgieva has stated that the consequences of coronavirus for the global economy will depend mainly on how long it lasts in China as well as possible spread to other countries because the long-lasting and more serious outbreaks will lead to the sharp and lingering decline of economic growth in China. Global negative effect will be aggravated by more serious failures in supply chains [8].

The so-called "innovation offshoring" has been gaining increasing popularity. It stipulates the attraction of qualified staff from less developed countries like South Africa, India, China, Brazil, Russia, and Ukraine to R\&D.

Therefore, offshoring launched in the late XX century has developed and expanded as an opportunity for large corporations to focus on the search for "cheap" labor. Meanwhile, each company had individual reasons to approach this practice and acted according to its own strategy of outsourcing abroad at their own risk.

By its nature, offshoring is the display of comparative advantages combined with all profits and losses of such process. In such a way, a country that provides the services wins at the expense of the other country that offshores the services due to jobs creation and investment attraction. According to World Bank estimations, G7 countries will lose $1-5 \%$ of jobs. Some researchers argue that the USA will have lost about 4 million jobs in services by 2022 . While the loss of capital and money laundering are related to a group of traditional offshore jurisdictions, the offshore services are mostly concentrated in several countries (over $70 \%$ of the market accounts for Ireland, India, Canada, and Israel; the share of Central and Eastern European Countries, including Ukraine, is growing fast).

Offshore zones are nongovernmental financial centers that provide a significant amount of credit and funding in currencies of other countries. Their characteristics are the following:

- lenient monetary legislation that protects the interests of investors not imposing excessive 
restrictions on financial institutions (low taxes, minor state interference);

- conducting foreign exchange and credit operations usually in foreign currency;

- legal assumption on currency sales when the official exchange rate is lower than the market one, and vice versa, currency purchase when the official exchange rate exceeds the market one;

- simplified taxation (usually the income tax in the off-shore jurisdictions is actually either absent or less than $1-2 \%$ or in most cases, the companies registered in these countries (but operating in other countries) do not pay any taxes except for annual fee regardless of gained profits) [9].

For example, the NASA Space Flight Center in Wallops (Virginia, USA) successfully launched on 17 November 2018 the Antares launch vehicle. The first-stage core of the launch vehicle was developed by the State Institution "Design Bureau "Pivdenne" and manufactured by the Production Association "Pivdenmash" in cooperation with Ukrainian companies "Hartron-ARKOS" (Harkiv), "Kyivprylad", "Hartron-YCOM" (Zaporizhzhya), "CHEZARA", "RAPID" (Chernihiv), etc. It was the ninth launch of Antares accomplished by the contract with NASA. On 17 April 2019 at 11:46 P.M. Kyiv time, Antares was successfully launched the tenth time and was supported from the Design Bureau "Pivdenne" facilities online. The project is an example of the cooperation of companies in the space sector of Ukraine in international space projects, consistent foreign economic activity, and the good position of the Ukrainian rocket and space industry on the global space market [10].

IT-outsourcing and outsourcing of business processes are the dominating directions on the outsourcing market. These types of services outsourcing in Ukraine are the most attractive for private capital. In 2013, the largest share accounted for the contracts in IT-outsourcing $68.40 \%$, while $31.6 \%$ - for the outsourcing of business processes. The number of IT-outsourcing contracts had grown by $8 \%$, while that of the business processes had fallen by $9 \%$. The cost of contracts had declined for both types: IToutsourcing by $8 \%$ down to $\$ 13.5$ billion and business processes - by $37 \%$ down to $\$ 5.2$ billion (11 The Global ISG Outsourcing Index, 2013) [11].

The analysis of investment dynamics in 2012-2019 shows that off-shore companies from about 40 jurisdictions operate in Ukraine, yet Cyprus is the most popular. Over $90 \%$ of investment from Ukraine to other countries is the investment to this island country [12].

The second position by the volumes of investment is occupied by the Shell Companies that belong to American investment in Delaware, Wyoming, etc. For Shell Companies, Ukraine is the country with substantial economic capacity, therefore, the activity is mostly related to the construction and exploitation of the petrol stations network and sales of fuel and lubricants. As a partner for Ukraine, Shell Companies are trying to develop mutually advantageous relations with Ukrainian companies to help improve the energy independence of the country, search for and develop the not easily accessible hydrocarbons, provide high-quality goods to customers, introduce advanced technologies, and encourage innovations [13].

Large corporations operating in the global competition system now have access to technologies as the major strategic asset and economic product - knowledge and development of intellectual capital. It is worth mentioning that technologies do not bring value by themselves. The technology at an enterprise cannot be considered isolated from organizational, economic, and social processes. The impact of technologies is related, in particular, to:

- improvement of products (new products with new functions, higher quality and reliability, less production cost) and modernization of their life cycles (replacement of the products by new generations based on more advanced technologies);

- improvement of design and production processes (reduced design cycle and achievement of complete production power, quality improvement, production cost reduction, production flexibility expansion);

- establishment of logistics processes and efficient trade reaction to the needs of consumers (e-data exchange, flow distribution without the storage of supplies at the intermediary warehouses, management decentralization);

- promotion of the efficiency of business processes (information technologies contribute to quicker determining the market opportunities, data exchange at any distance, unification of management tools)

- prevailing software, comprehensive decentralization of managerial decisions);

- knowledge development and standardization of educational processes (preparation of workforce for the use of advanced technologies, unification of control, organizational, and program decisions as a condition of technology use, organizational training, changes in organizational culture).

Cyprus remains the major investor in Ukraine. It is worth mentioning that the share of investment in the offshore jurisdiction, namely the Virgin Islands, is insignificant (about \$57 million, i.e. less than one percent).

Therefore, it can be concluded that almost all investment from Ukraine is directed into the offshore territories. The situation remains relatively consistent in the entire period under research and ranges within 88\% - 94\% regardless of the growing investment in foreign countries and in the mentioned offshore territories in general [14].

Table 2 shows the major export and import partners of Ukraine and border regions in 2019. 
Main foreign trade partners of Ukraine and border regions in 2019

\begin{tabular}{|c|l|l|}
\hline Border region & \multicolumn{1}{|c|}{ Export } & \multicolumn{1}{c|}{ Import } \\
\hline Lvivska oblast & $\begin{array}{l}\text { Poland, Germany, Czech Republic, } \\
\text { Denmark, Slovakia. }\end{array}$ & Poland, Germany, China, Russia. \\
\hline Zakarpatska oblast & $\begin{array}{l}\text { Hungary, Germany, Austria, } \\
\text { Slovakia, Poland. }\end{array}$ & $\begin{array}{l}\text { China, Germany, Czech Republic, } \\
\text { Hungary. }\end{array}$ \\
\hline Volynska oblast & $\begin{array}{l}\text { Germany, Russia, Hungary, Poland, } \\
\text { Kazakhstan. }\end{array}$ & $\begin{array}{l}\text { Germany, Hungary, Poland, France, } \\
\text { Russia, the Netherlands. }\end{array}$ \\
\hline $\begin{array}{c}\text { Ivano-Frankivska } \\
\text { oblast }\end{array}$ & $\begin{array}{l}\text { Romania, Slovakia, India, Poland, } \\
\text { Czech Republic, Turkey, Italy. }\end{array}$ & $\begin{array}{l}\text { Russia, Germany, Belarus, Poland, } \\
\text { China, Romania, Italy. }\end{array}$ \\
\hline $\begin{array}{c}\text { Chernivetska } \\
\text { oblast }\end{array}$ & $\begin{array}{l}\text { Romania, Poland, Germany, Turkey, } \\
\text { Belarus. }\end{array}$ & $\begin{array}{l}\text { Romania, Poland, Germany, Turkey, } \\
\text { China. }\end{array}$ \\
\hline Ukraine & $\begin{array}{l}\text { Poland, Germany, Italy, Turkey, } \\
\text { Russia, India. }\end{array}$ & $\begin{array}{l}\text { Germany, Poland, Italy, Belarus, } \\
\text { Russia, China. }\end{array}$ \\
\hline
\end{tabular}

*Developed by the author based on: [1]

Lately, the role of Poland as one of the major foreign trade partners of Ukraine has increased, partially outcompeting Russia. Yet, there are problems in forming efficient foreign trade relations, including the low diversification of the trade structure of Ukrainian export. For example, import of ideas, technologies, and know-how, exploitation of global demand secures the deep and elastic market for the products from the USA, China, and Germany [17].

The Table 3 shows the growth of goods export and import across oblasts and in the country each two years.

Goods export and import growth in $2010-2019, \%$

\begin{tabular}{|c|c|c|c|c|c|c|c|c|c|c|}
\hline $\begin{array}{l}\text { Oblast/count } \\
\text { ry }\end{array}$ & 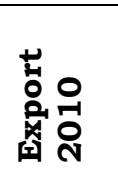 & 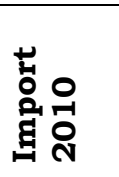 & 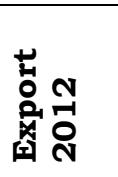 & 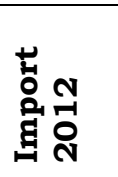 & 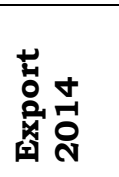 & 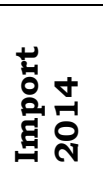 & 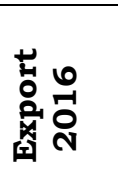 & 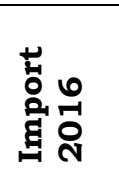 & 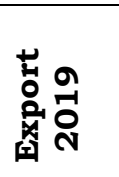 & 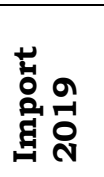 \\
\hline Lvivska & 122.7 & 125 & 111.8 & 105.3 & 101.1 & 93.1 & 105.7 & 117.4 & 116.2 & 114 \\
\hline Zakarpatska & 123.7 & 141.5 & 99.1 & 100.6 & 106.4 & 84.1 & 110.7 & 112.1 & 89.8 & 97.1 \\
\hline Volynska & 136.3 & 133.6 & 93.7 & 95.8 & 109 & 70.3 & 96.9 & 181.8 & 96.4 & 106.4 \\
\hline $\begin{array}{l}\text { Ivano- } \\
\text { Frankivska }\end{array}$ & 151.1 & 254.5 & 87.2 & 92.1 & 103.4 & 83.3 & 153.8 & 137.9 & 104.6 & 100 \\
\hline Chernivetska & 86.8 & 108.3 & 91.5 & 107.3 & 103.1 & 70.5 & 110.2 & 122.2 & 106.9 & 149.4 \\
\hline Ukraine & 129.6 & 133.7 & 100.6 & 102.5 & 86.5 & 71.8 & 95.4 & 104.6 & 105.8 & 106.3 \\
\hline
\end{tabular}

*Developed by the author based oni: [1]

While goods import in Ukraine generally exceeds export, the goods export of IvanoFrankivska and Chernivetska oblasts mostly exceeds import, yet, in 2018, the exports haresin the total goods export of Ukraine are $1.8 \%$ and $0.4 \%$, respectively. The distinctive feature of export in the selected oblasts is that the share of export and import of machines, equipment and mechanisms and electrical equipment prevail here, except for Chernivetska oblast. Regarding the goods import structure of Ukraine (prevailing share of mineral products) and border regions, it is worth emphasizing that the import of Zakarpatska and Ivano-Frankivska oblasts is mostly represented by machines and equipment, Lvivska and Volynska oblasts - by mineral products, and Chernivetska oblast-by textile materials and textile products.

Ukraine maintains close relations with European Union in service exchange. Thus, in
2013, the foreign services trade balance was negative but, in 2014, export considerably exceeded import. A significant reduction of services exchange volumes was observed in 2015. The services trade balance also reduced and was \$177.8 mlnin 2015 . Due to the EU-Ukraine Association Agreement and freetrade are azone coming into force as of 1 January 2016, the research of foreign trade relations trends is getting importance. The positive trends were observed in 2016 because the services export volume and foreign trade in services balance were growing substantially. In general, there was a slight fall in the export and import of services in Ukraine in 2012 - 2017 (by $21.2 \%$ and $18.7 \%$ )and services export growth almost twice in border regions. Significant growth in services growth was peculiar to Zakarpatska and Chernivetska oblasts (292.2 \% and $160.4 \%)$. Zakarpatska oblast also leads by services export per capita, which was $\$ 204.2$ in 2017. 
The dynamics of goods and services export testifies to the growing level of export orientation of the Ukrainian economy. Similar trends are peculiar to border oblasts. Lvivska oblast is the leader by the share in services export of border regions with a $44.8 \%$ rate in 2012 and $48.8 \%$ in 2017. The strongest growth was observed in Zakarpatska oblast, where the export orientation level reached $55.38 \%$ in 2017 , exceeding the level of all oblasts not only in the Western Region but also in Ukraine in general.

The services export structure remained almost unchanged in 2019: transport services (about $50 \%$ ), material resources processing (about20\%), telecommunication, computer, and information services (about $15 \%$ of the total export services in Ukraine). Regarding the services import, the share of transport services amounts to about 25\%, tourism services - 20\%, public and governmental services- $10.4 \%$. The positive balance of foreign tradein services of border regions in 2010 - 2019 and its growth testify to a considerable increase of the export capacity of the analyzed Ukrainian oblasts in the foreign trade in services.

Mostly, about ten world leaders by the volume of export secure almost $50 \%$ of export. Therefore, there is a trend towards the geographic concentration of export. Ukraine's share in the global export of goods is less than 1\%. In 2019, over 200 countries were the foreign trade partners of Ukraine: Russia, China, Poland, Italy, Germany, India, Hungary, Belarus, USA, Turkey, France, Czech Republic, Sweden, Switzerland, and Austria. It is worth mentioning that lately, the EU has become the main partner for Ukraine because almost $50 \%$ of goods and services are exported to Europe.

Before the events of 2013, Russia's market was the major export partner of Ukraine. Some share of Ukrainian machine-building companies found the mselvesin Ukrainian territories occupied by Russia, so the rates of domestic machine-building export have reduced.

The following are the problems of the foreign trade relations:

restrained processes of structural reconstruction of the domestic economy, high level of import dependence, and technological retardation of production that prevent strategic position in domestic producers on foreign goods and services markets in compliance with the national interests;

high level of goods concentration of export and import operations that cause sahigh sensitivity of economic system evento slight fluctuations of foreign markets;

deformation of goods structure of import and export and their unbalanced nature that testifies to the need to take urgent steps to wards the forming of atarget system of public regulation measure sand the stimulation of the foreign economic activity to overcome the accumulated economic problems of the country ingeneral.

Conclusions, reflections, and prospects for future research. It is impossible to completely stop the globalization processes, especially nowadays, in times of pandemics. Yet, certainly, we will wake up in an entirely different global economic and geopolitical system. The geographic structure of raw materials and semi-finished products supply will certainly change slightly. It is related, among other things, to the relationship between European and Chinese economies - the virus has definitely shown strong dependence on the Chinese role in European value chains. For example, European production of certain products from the "white economy" sector like protective masks, costumes, medical equipment and materials is growing. The question is whether the changes will take place for certain and how long it will take, or whether these are only political claims generated by current problems in the functioning of global value chains. However, these value chains will be restored due to the growth of the European economy. The course of development of strategic economic sectors will possibly change. In these conditions, Ukraine can be the winner but it is important to reform the strategic economic sectors in the first place because we remain to be the country of raw materials export.

Pandemics is a kind of lesson for the creators of socio-economic life but it also opens some perspectives and changes understanding that a person lives not only by means of new technologies. Although, for sure, they help communicating or, for example, distance learning. Yet, nowadays, under the impact of social pressure, we will focus more on reforming the military-industrial complex, healthcare, search for a vaccine, and overcoming the COVID-19 consequences.

\section{ІНТЕГРАЦІЯ ПРОМИСАОВІСТІ УКРАЇНИ У ГАОБААЬНІ ААНЦЮГИ ДОДАНОЇ ВАРТОСТІ}

Стельмах Христина Петрівна, канд. екон. наук, науковий співробітник ДУ «Інститут регіональних досліджень ім. М. І. Долішнього НАН України, 79026, м. Аьвів, вул. Козельницька, 4, е-таіl: stelmakhkristina@gmail.com, ORCID: https://orcid.org/0000-0001-6094-8790

У статті досліджено формування глобальних манцюгів доданої вартості, визначено особливості їх формування на прикладі машинобудівних підприємств. Предметом дослідження в статті є окреслення інтеграції промисловості України у глобальні цанцюги доданої вартості. Мета полягає у розробці положень щодо налагодження формування глобальних манцюгів доданої вартості в сучасних економічних умовах. Безліч вчених стверджують, що глобалізація дала можливість своєрідної оптимізації світової економіки. 
Вıасне, спалах "COVID-19" спричиняє поточний економічний спад і одночасно повну переорієнтацію могістики світової торгівці. Завданнями є дослідження особливостей офшорингу на прикладі функціонування промислових підприємств нашої країни. Визначальним є формування надійної системи моніторингу постачальників, яка також відображає вагомість вибору спеціалістів із постачання. За допомогою системного аналізу визначено, що при переважній наявності бар'єрів для розміщення іноземного капіталу в Україні існують певні перспективи інтеграції промислових підприємств у глобальні манцюги створення вартості. За результатами дослідження, попри наявне соціально-економічне становище, Україна є привабливою для іноземного інвестування через значну віддачу від капітальних вкцадень, ніж у відповідних видах економічної діяльності Європейських країн, вигідне геополітичне положення, наявність дешевої і водночас кваліфікованої робочої сили. Ефективний соціальноекономічний розвиток не можливий без сектору високих технологій та інноваційної діяльності країни. Проте, політична нестабільність та сукупність бар'єрів щодо залучення іноземних інвестицій залишаються ключовими проблемами на шляху соціально-економічного розвитку.

Ключові слова: глобальні манцюги доданої вартості, іноземні інвестиції, регіони, овшоринг, аутсорсинг, промисловість, машинобудування, автомобімебудування.

\section{ИНТЕГРАЦИЯ ПРОМЫШАЕННОСТИ УКРАИНЫ В ГАОБААЬНЫЕ ЦЕПОЧКИ ДОБАВАЕННОЙ СтОИМости}

Стельмах Кристина Петровна, канд. экон. наук, научный сотрудник ГУ «Институт региональных исследований им. М. И. Нижнего НАН Украины, 79026, г.. Аьвов, ул. Козельницкая, 4, е-таil: stelmakhkristina@gmail.com, ORCID: http://orcid.org/0000-0001-6094-8790

В статье исследовано формирование глобальных цепочек добавленной стоимости, определены особенности их формирования на примере машиностроительных предприятий. Предметом исследования в статье является определение интеграции промышленности Украины в глобальные цепочки добавленной стоимости. Цель заключается в разработке положений по налаживанию формирования глобальных цепей добавленной стоимости в современных экономических условиях. Множество ученых утверждают, что глобализация дала возможность своеобразной оптимизации мировой экономики. Собственно, вспышка "COVID-19" вызывает текущий экономический спад и одновременно полную переориентацию могистики мировой торговли. Задачами в статье есть исследование особенностей офшоринга на примере функционирования промышленных предприятий нашей страны. Определяющим аспектом сегодня есть формирование надежной системы мониторинга поставщиков, которая также отражает значимость выбора специалистов по снабжению. С помощью системного анализа определено, что при подавляющем наличии барьеров для размещения иностранного капитала в Украине существуют определенные перспективы интеграции промышленных предприятий в глобальные цепочки создания стоимости. По результатам исследования, несмотря на имеющееся социально-экономическую ситуацию, Украина однозначно привлекает инвесторов из-за значительной отдачи от капитальных вложений, чем в соответствующих видах экономической деятельности европейских стран, выгодное геополитическое поможение, наличие дешевой и одновременно квалифицированной рабочей силы. Эффективный социально-экономическое развитие невозможно без сектора высоких технологий и инновационной деятельности страны. Однако, политическая нестабильность и совокупность барьеров по привлечению иностранных инвестиций остаются главными проблемами на пути социально-экономического развития.

Кмючевые слова: глобальные цепочки добавленной стоимости, иностранные инвестиции, регионы, овшоринг, аутсорсинг, промышленность, машиностроение, автомобилестроение.

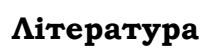

1. Kaplinsky R., Morris M. A handbook for Value Chain Research / The International Development Research Centre, 2001. 109 p. URL: http://www.prism.uct.ac.za/Papers/VchNov01.pdf

2. Неуров I. Аутсорсинг закупівель: світовий досвід і вітчизняні перспективи. Вісник Наиіонального університету "Аьвівсъка політехніка". 2009. № 640. С. 155-162.

3. IT-pulse. Обслуживание компьютеров. URL: http://www.it-pulse.com.ua/informaciya-2.html.

4. Карпова Т. Аутсорсинг как эффективный способ взаимодействия махых и крупных предприятий и его роль в повышении конкурентоспособности малых предприятий. Науковий вісник: Фінанси, банки, інвестииї. 2012. № 3. С. 94-96.

5. Shih S. Me-too is not my style: Challenge difficulties, break through bottlenecks, create values / S. Shih // Taipei : The Acer Foundation, 1996. 247 p.

6. Filipenko, A. and Filipenko, V., “The Theory of International Economic Integration", Naukovyj visnyk Skhidnoievropejs'koho natsional'noho universytetu imeni Lesi Ukrainky. Mizhnarodni vidnosyny. 2013. vol. 10. pp. 4-12.

7. Moravcsik A. Europe's Integration at Century's End / A. Moravcsik / Centralization or Fragmentation? Europe Facing the Challenges of Deepening, Diversity and Democracy. - New York : Council on Foreign Relations, 1998.

8. : Укрінформ. Мультимедійна платформа. URL: https://www.ukrinform.ua
} 
9. Волкова Ю.О.,. Розвиток офшорних центрів у системі міжнародного бізнесу. Формування ринкових відносин в Україні, 2008. № 1. С.43-48.

10. Укрінформ. Мультимедійна платформа. URL: https://www.ukrinform.ua/rubric-technology/2877494ukrainskoamerikanska-raketa-antares-vivela-v-kosmos-korabel-z-vantazem-dla-mks.html

11. The Global Outsourcing Report URL: https://www.markminevich.com/pdf/WB_FINAL.PDF

12. Шамбост Е. Енциклопедія оффшорних зон: посібник для магістерських курсів університету Економіки. Москва; МГУ. 2008.

13. Офіційний сайт групи компаній «SHELL». URL: https://www.shell.ua

14. Шереметинська О., Савчук I. Вплив офшорних зон на економіку України. Економічний простір. 2016. № 105. С. 58-66.

15. Кулицький С. Сучасний етап розвитку оборонно-промислового комплексу і виробництва продукції подвійного призначення в Україні. Україна: подіï, фракти, коментарі. 2018. № 5. С. 54-69.

\section{References}

1. Kaplinsky R., Morris M. (2001) A handbook for Value Chain Research. The International Development Research Centre. Available at: http://www.prism.uct.ac.za/Papers/VchNov01.pdf

2. Neurov I. (2009) Autsorsynh zakupivel: svitovyi dosvid i vitchyznyani perspectyvy [Outsourcing of purchase: global experience and domestic perspectives]. Visnyk Natsionalnoho universytetu "Lvivska politehnika" [Bulletin of the National University "Lviv Polytechnics"], no 640, pp 155-162.

3. IT-pulse. Obsluzhyvanie kompyuterov [IT-pulse. Computer service] (2021). Available at: http://www.itpulse.com.ua/informaciya-2.html.

4. Karpova T. (2012) Autsorsing kak effectivnyi sposob vzayemodeistviya malyh i krupnyh predpriyatiyi eho rol $\mathrm{v}$ povyshenii konkurentosposobnosti malyh predpriyatiy [Outsourcing as an efficient way to interact between small and large companies and its role in the growing competitiveness of small companies]. Naukovyi visnyk: Finansy, banky, investytsiyi [Scientific Bulletin: Finance, Banks, Investment], no № 3. pp. 94-96.

5. Shih S. (1996) Me-too is not my style: Challenge difficulties, break through bottlenecks, create values . Taipei : The Acer Foundation .

6. Filipenko, A. and Filipenko, V., (2013) The Theory of International Economic Integration, Naukovyj visnyk Skhidnoievropejs'koho natsional'noho universytetu imeni Lesi Ukrainky [Scientific bulletin of Lesya Ukrayinka Eastern European University]. Mizhnarodni vidnosyny [International relations], vol. 10. pp. 4-12.

7. Moravcsik A. (1998) Europe Facing the Challenges of Deepening Diversity and Democracy. New York : Council on Foreign Relations.

8. : Ukrinform.. Available at: ttps://www.ukrinform.ua

9. VolkovaY.O (2008) Rozvytok ofshornyh tsentriv u systemi mizhnarodnoho biznesu [Offshore centers development in the system of international business]. Formuvannya rynkovyh vidnosyn $v$ Ukrayini [Market relations forming in Ukraine], no 1., pp. 43-48.

10. Ukrinform. Available at: https://www.ukrinform.ua/rubric-technology/2877494ukrainskoamerikanska-raketa-antares-vivela-v-kosmos-korabel-z-vantazem-dla-mks.html

11. The Global Outsourcing Report URL: https://www.markminevich.com/pdf/WB_FINAL.PDF

12. Shambost E. (2008) Entsyklopediya ofshornyh zon: posibnyk dlya mahisterskyh kursiv Universytetu ekonomiky [Offshore zones encyclopedia: handbook for masters courses in the Economy University]. Moskva: MGU [Moscow: MGU].

13. Ofitsiynyi sayt hryou kompaniy SHELL [Official website of the SHELL company group ]. Available at: https://www.shell.ua

14. Sheremetynska O., Savchuk I. (2016) Vplyv ofshornyh zon na ekonomiku Ukrayiny [Offshore zones' impact on Ukrainian economy]. Economichnyiprostir [Economicspace], no 105, pp 58-66.

15. KulytskyiS. (2018) Suchasnyi etap rozvytku oboronno-promyslovoho kompleksu i vyrobnytstva produktsiyi podviynoho pryznachennya [Modern condition of military-industrial facilities and production of dual-use items]. Ukrayina: podiyi, fakty, komentari [Ukraine: events, facts, comments], no 5, pp 54-69.

Статтю отримано 15 мютого 2021 р. 